\title{
Predator-prey eddy in heterotrophic nanoflagellate-bacteria relationships in a bay on the northeastern Pacific coast of Japan
}

\author{
Tsuneo Tanaka*, Akira Taniguchi \\ Laboratory of Biological Oceanography, Faculty of Agriculture, Tohoku University, Sendai 981-0914, Japan
}

\begin{abstract}
A new scheme has been recently proposed by Tanaka et al. (1997; Aquat Microb Ecol 13:249-256) to illustrate the temporal variation in the numerical relationship between heterotrophic nanoflagellates (HNF) and bacteria on both short-term and seasonal scales. To clarify this scheme, seasonal variations in abundance of HNF and bacteria, together with environmental variables, were monitored at 1 to 3 dintervals in Onagawa Bay on the northeastern Pacific coast of Japan. In addition, bacterial growth rates were also measured weekly or bi-monthly. As expected from the marked seasonality of environmental variables, bacterial growth rate showed distinct seasonal variation, being higher in warmer seasons and vice versa. The seasonal variation of bacterial abundance in nature, however, was only 1 order of magnitude, while HNF abundance showed marked seasonal changes. On shorter temporal scales, peaks of bacterial abundance were usually followed by increases in $\mathrm{HNF}$ abundance with a lag of 2 to $7 \mathrm{~d}$, and bacterial and HNF abundances changed with 2 to $14 \mathrm{~d}$ and 3 to $17 \mathrm{~d}$ periods, respectively, indicating so-called predator-prey oscillations. These values generally agree with previously reported values, even though there were temporal and spatial differences. These predator-prey oscillations were confined to a particular region in phase space during a period of ca 1 mo and showed a sequential movement in a anticlockwise and/or clockwise direction. Such movement was termed the predator-prey eddy. On annual scales, the eddy's position and magnitude were different between seasons, but the eddy was confined to a vertically elongated elliptical region in phase space which was similar to findings in our previous study. These results support our contention, namely, that the predator-prey eddy of the HNF-bacteria system always exists and continuously migrates over a certain region of phase space on an annual basis.
\end{abstract}

KEY WORDS: Heterotrophic nanoflagellates $\cdot$ Marine bacteria $\cdot$ Short-term fluctuations $\cdot$ Predator-prey eddy

\section{INTRODUCTION}

Heterotrophic nanoflagellates (HNF) are now considered to play an important role in regulating bacterial abundance and recycling inorganic nutrients and dissolved organic matter (Fenchel 1982a to d, Azam et al. 1983, Andersson et al. 1985, Goldman \& Caron 1985, Sherr et al. 1986). It has been reported that HNF and bacteria are widely distributed and abundant, on the order of $10^{1}$ to $10^{4}$, and $10^{5}$ to $10^{7}$ cells ml ${ }^{-1}$, respectively (e.g. van Es \& Meyer-Reil 1982, Fenchel 1986).

\footnotetext{
- Present address: Station Zoologique, BP 28, F-06234 Ville-
} franche-sur-Mer, France. E-mail: tanaka@ccrv.obs-vlfr.fr
Statistical analysis shows that HNF abundance positively correlates with bacterial abundance across a wide range of aquatic environments (Berninger et al. 1991, Sanders et al. 1992, Gasol \& Vaqué 1993). The numerical relationship between bacteria and HNF is often simplified to a ratio of $\mathrm{ca} 10^{3}: 1$, and this suggests that both HNF and bacteria respond to changing environmental factors in parallel over wide geographical and temporal scales (Wright \& Coffin 1984a). In fact this numerical relationship actually shows wide variability, up to 2 orders of magnitude $\left(10^{2}: 1\right.$ to $10^{4}: 1$, see Sanders et al. 1992, their Fig. 2). Within each system, it has often been observed that bacterial abundance is less variable, but HNF abundance shows marked sea- 
sonal fluctuations (Wright \& Coffin 1984a, Davis et al 1985, Iwamoto et al. 1994, Mostajir et al. 1995, Tanaka et al. 1997). In addition, several reports revealed that the abundances of bacteria and HNF show regular cyclic changes with a certain lag phase, i.e. predatorprey oscillations, when monitoring was done at shorter intervals (Fenchel 1982d, Davis et al. 1985, Andersen \& Sørensen 1986, Nakamura et al. 1994, Tanaka \& Taniguchi 1996)

However, no adequate explanation has been given for the numerical relationship established between HNF and bacteria. Based on seasonal monitoring conducted in Onagawa Bay on the northeastern Pacific coast of Japan, we recently proposed a new scheme to illustrate the temporal variation in the numerical relationship between HNF and bacteria on both shortterm and seasonal scales (Fig. 1, Tanaka et al. 1997). Namely, bacterial abundance varied within a narrow range throughout the year, while HNF abundance showed marked seasonal changes. Short-term observations conducted each month in summer and winter revealed that peaks of bacterial abundance were usually followed by increases in HNF abundance with a certain lag phase and that both abundances changed

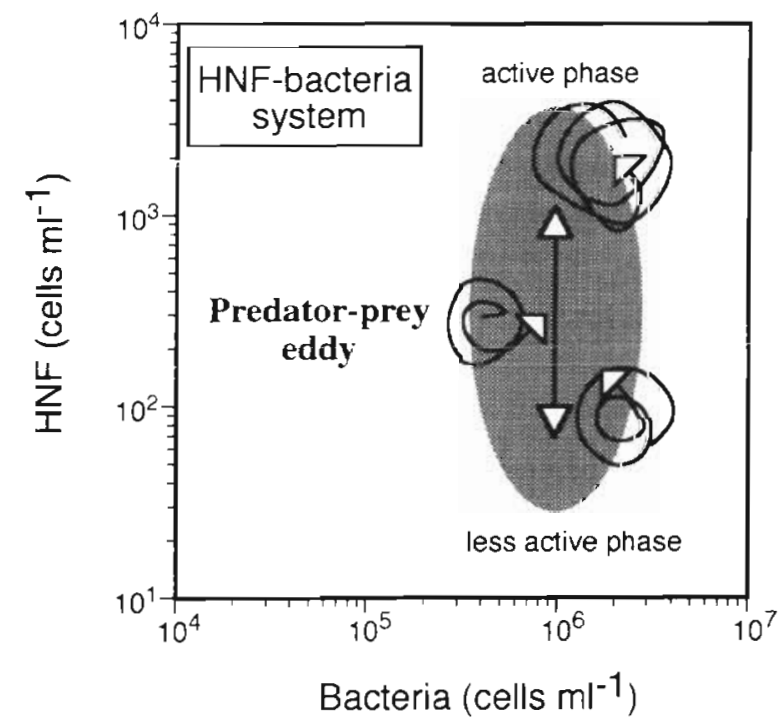

Fig. 1. Schematic diagram of the numerical relationship between heterotrophic nanflagellates (HFN) and bacteria (adapted from Tanaka et al. 1997). Three predator-prey eddies show the numerical relationship between HNF and bacteria in phase space on a shorter temporal scale, although we consider the eddy to be continuous in time. The shaded area shows the region within which the eddy migrates annually in Onagawa Bay; the elliptical form reflects the greater variation in HNF abundances than in bacterial abundances. 'Active phase' and 'less active phase' respectively mean rapid and slow material cycling through the HNF-bacteria system, because both metabolic activities and HNF abundance are high in warmer seasons and vice versa in the remaining period cyclically, indicating predator-prey oscillations. When HNF abundance was plotted against bacterial abundance, i.e. phase space plotting, using the results obtained by short-term monitoring, these predatorprey oscillations were confined to certain areas, the position and magnitude of which differed in time. In addition, since the HNF-bacteria system moved in clockwise and anticlockwise directions or a complicated succession in phase space, we termed such areas predator-prey eddies. The seasonal relationship between the 2 groups of microorganisms was confined to a vertically elongated elliptical region in phase space (Fig. 1). Based on seasonal and short-term changes of their abundance, the annual cycle of the HNF-bacteria relationship can be considered a continual migration of the predator-prey eddy in phase space. This diagram, however, was based on annual data sets collected by weekly observations, and 2 d interval observations were limited to 1 mo each in summer and winter.

Thus, to clarify our scheme, intensive sampling with shorter time intervals was successively carried out for 1 yr. We intensively monitored the abundance of HNF and bacteria, together with environmental variables, at 1 to 3 d intervals. Duplicate counts for enumeration of HNF and bacteria were always conducted to minimize the counting error. Bacterial growth rates were also measured weekly or bi-monthly. In this paper, we discuss the existence of the predator-prey eddy of HNF-bacteria associations in nature, the continuously migrating behavior of the eddy in phase space, and its annual range in Onagawa Bay, Japan.

\section{MATERIALS AND METHODS}

Study site. Onagawa Bay opens to the western North Pacific Ocean, and its topography allows water exchange to some extent between the inner and outer bay (Sasaki et al. 1995). The innermost part of the bay is separated from the main basin by several long breakwaters, which jut into the bay from both sides and constrict the entrance, forming a semi-enclosed embayment. There is no significant inflow of freshwater, and only very small streams enter Onagawa Bay. We fixed one station (Stn 1: $38^{\circ} 26.12^{\prime} \mathrm{N}$, $141^{\circ} 27.62^{\prime} \mathrm{E}$ ) at the inner breakwater near Onagawa Marine Laboratory, Tohoku University (Fig. 2). This station is subjected to tidal change so that depth to the bottom changes from ca 5 to $6.5 \mathrm{~m}$ throughout the year. Thus the difference in tidal height between spring and neap tides is small.

Environmental variables and $\mathrm{HNF}$ and bacterial abundances. A seasonal field survey was conducted at Stn 1 in the morning (06:00 to 08:00 h JST) from January 1996 to February 1997. During the period from 


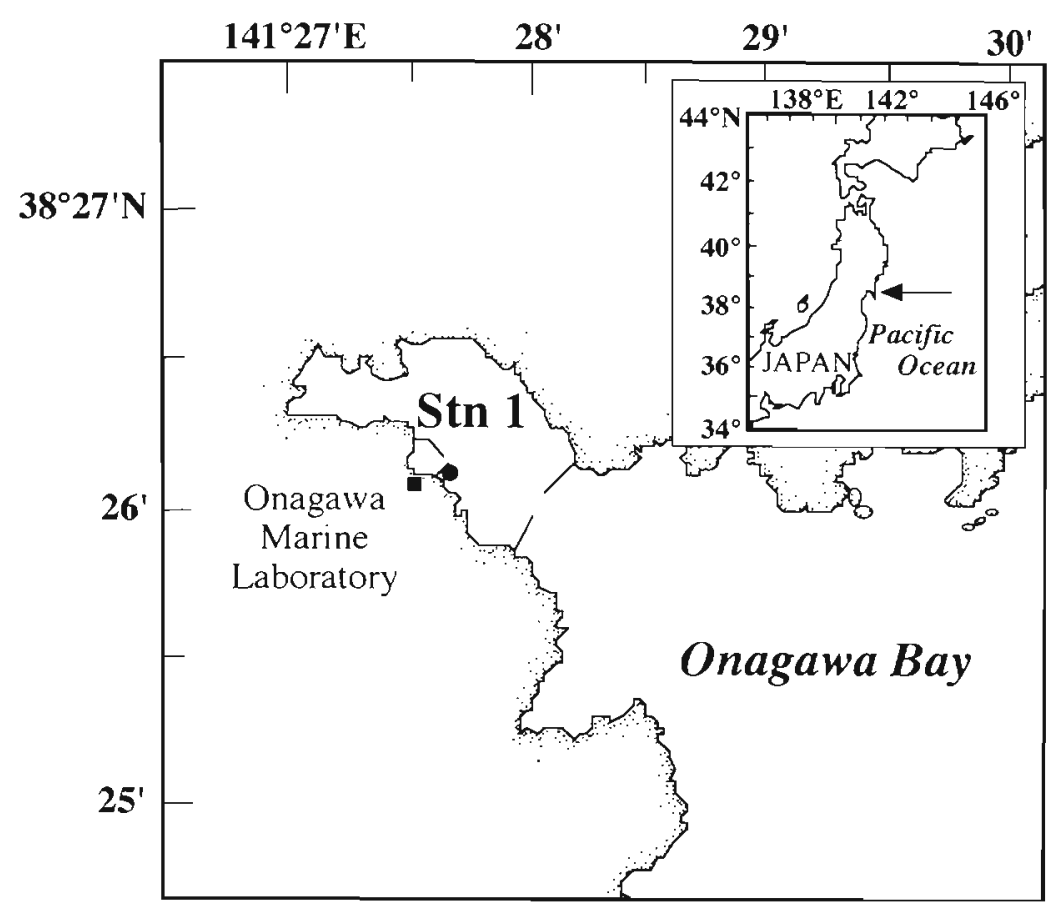

Fig. 2. Location of the sampling station (Stn 1) in Onagawa Bay, Japan

pore size, Nigrosin-stained Nuclepore filter. The HNF were stained with DAPI for 5 min (final conc. $1 \mu \mathrm{g} \mathrm{ml} \mathrm{ml}^{-1}$ ), thereafter with 3-6diamino-acridine hemi-sulfate (proflavine; final conc. $0.06 \mu \mathrm{g} \mathrm{ml}^{-1}$; Haas 1982) and finally collected on the filter.

All the filters were examined under a Nikon epifluorescence microscope equipped with a $50 \mathrm{~W}$ mercury lamp at $1000 \times$ magnification. Over 400 bacterial cells were counted under UV excitation (330 to $380 \mathrm{~nm}$ with a $420 \mathrm{~nm}$ barrier filter) in at least 10 fields. Heterotrophic flagellates which emit green fluorescence under blue excitation (410 to $485 \mathrm{~nm}$ with a $515 \mathrm{~nm}$ barrier filter) and blue fluorescence under UV excitation were counted in at least 25 fields; over 100 cells per filter were enumerated, and sized with an ocular micrometer. Cell volume and equivalent spherical diameter (ESD) of these heterotrophs were then calculated by assuming their shape to be spherical or ellipsoidal. Throughout the study period, heterotrophic flagellates of 2 to $5 \mu \mathrm{m}$ ESD dominated, representing 62 to $96 \%$

5 February 1996 to 5 February 1997, monitoring was conducted at 2 or 3 d intervals, and during August 1996, daily samples were taken. Temperatures at 0 and $5 \mathrm{~m}$ were recorded for each sampling time. Water samples for determination of 4 nutrients $\left(\mathrm{NO}_{2}, \mathrm{NO}_{3}\right.$ $\mathrm{NH}_{4}, \mathrm{PO}_{4}$ ) and chlorophyll a (chl a) and for microscopic enumeration of HNF and bacteria were collected with a Kitahara water bottle from the $2 \mathrm{~m}$ layer. The water samples were always processed in Onagawa Marine Laboratory within $30 \mathrm{~min}$ after obtaining the samples as described below.

Samples for chl a were filtered onto Whatman GF/F glass fiber filters, extracted in $90 \%$ acetone and determined by the method of Yentsch \& Menzel (1963) with a HITACHI 139 spectrofluorometer. Concentrations of the 4 nutrients in the filtrate were determined with a Flow Solution spectrophotometer system (manual methods of Parsons et al. [1984] adapted for an automated system).

From each water bottle sample, duplicate $100 \mathrm{ml}$ subsamples for enumeration of HNF and bacteria were fixed with glutaraldehyde (final conc. $0.9 \%$ ) and kept refrigerated (ca $5^{\circ} \mathrm{C}$. Bacteria in each $10 \mathrm{ml}$ aliquot from the 2 subsamples were stained with $4^{\prime} 6$-diamidino-2-phenylindole (DAPI final conc. $1 \mu \mathrm{g} \mathrm{ml} \mathrm{m}^{-1}$ ) for $5 \mathrm{~min}$ and then a $3 \mathrm{ml}$ subsample was filtered onto a $25 \mathrm{~mm}, 0.2 \mu \mathrm{m}$ pore size Nigrosin-stained Nuclepore filter (Porter \& Feig 1980). Another aliquot (15 to $50 \mathrm{ml}$ ) was taken from the $100 \mathrm{ml}$ sample for HNF enumeration and concentrated to ca $10 \mathrm{ml}$ on a $25 \mathrm{~mm}, 0.6 \mu \mathrm{m}$ (mean $81 \%$ ) in cell number of all heterotrophic nanoplankters between 2 and $20 \mu \mathrm{m}$ ESD. Since most bacterivores have been reported to be smaller than $5 \mu \mathrm{m}$ in size (Sherr \& Sherr 1991), we considered the heterotrophic flagellates of 2 to $5 \mu \mathrm{m}$ ESD to be bacterivores. Although it has been reported that some of the heterotrophic nanoplankters larger than $5 \mu \mathrm{m}$ could also be bacterivores (e.g. Fenchel 1982a, Goldman \& Caron 1985, Sherr \& Sherr 1987), the general trend of the present results would not be affected due to the predominance of flagellates of 2 to $5 \mu \mathrm{m} \mathrm{ESD}$ Hereafter, we refer to the flagellates of 2 to $5 \mu \mathrm{m} \mathrm{ESD}$ as 'HNF'.

One filter for enumeration of bacteria and 1 for HNF was prepared for each duplicate subsample from the water bottle, making 4 filters in total. The abundance of bacteria and HNF are reported as the mean value of 2 counts, unless stated otherwise. The ranges of the duplicate counts from each water bottle were usually $<20 \%$ of the mean values.

Bacterial growth rate. Since our previous study (Tanaka et al. 1997) indicated that the limited seasonal variation of bacterial abundance in Onagawa Bay is due to top-down (predation control) rather than bottom-up (substrate limitation) control, the bacterial growth rate was measured in this study in the absence of bacterivores. To measure the growth rate at 1 or $2 \mathrm{wk}$ intervals throughout the year, we deliberately selected the quickest method, i.e. the size fractionation method, where the increase in bacterial cell number 
after removing bacterivores was counted with an epifluorescence microscope (e.g. Wright \& Coffin 1984b). This method can be affected by dissolved organic matter exudate from some fragile cells (Ferguson et al. 1984) and/or the elimination of particulate organic matter including detritus and phytoplankton (Güde 1986) by the filtration processes. However, since we employed the same method throughout this study, the results obtained should reflect the seasonal trend of bacterial growth capability.

Water for the growth experiments was sampled at $2 \mathrm{~m}$ at $\operatorname{Stn} 1$ almost weekly during the period from June 1996 to June 1997 by using a sampling system which consisted of a teflon diaphragm pump, an air compressor and NRK ${ }^{\oplus}$ universal tubing (Nihon Rikagaku Kikai, Japan). The system was precleaned thoroughly by sequential rinsing with $1 \mathrm{~N} \mathrm{HCl}$-distilled water, tap water, distilled water and finally with seawater in situ. After cleaning, ca 81 of water were pumped at a rate of ca $1 \mathrm{l} \mathrm{min} \mathrm{m}^{-1}$ into a $20 \mathrm{l}$ precleaned polycarbonate container, which was placed under a tarpaulin to prevent exposure to direct sunlight. In the laboratory, aliquots of the water sample were filtered through a $20 \mu \mathrm{m}$ nylon mesh by gravity, and then through a Nuclepore filter (0.6 $\mu \mathrm{m}$ pore size) under gentle negative pressure (<50 mm Hg) using a polysulfone filtration apparatus. To avoid clogging, the volume of each aliquot was adjusted to $100-300 \mathrm{ml}$. By repeated filtrations, ca $1 \mathrm{l}$ of filtrate $(<0.6 \mu \mathrm{m})$ was collected in a 11 polycarbonate bottle, which was precleaned by modifying the protocol of Fitzwater et al. (1982), i.e. sequential overnight soaks in detergent and in $1 \mathrm{~N} \mathrm{HCl}$ (repeated twice) and then in $2 \%$ nitric acid, followed by 3 rinses with $1 \mathrm{~N} \mathrm{HCl}$ using distilled-deionized water. The bottles were kept soaked in $1 \mathrm{~N} \mathrm{HCl}$ distilled-deionized water when not in use.

Just before incubation, a $100 \mathrm{ml}$ aliquot was taken from the bottle to check for contamination of larger organisms than bacteria, or potential bacterivores, as well as to enumerate bacteria, by the same methods described in the preceding sections. The incubation was conducted in the shade in a seawater tank on land where the temperature was kept within $\pm 2^{\circ} \mathrm{C}$ of the in situ temperature by circulating natural seawater. Duplicate $10 \mathrm{ml}$ subsamples for enumeration of bacteria were withdrawn with a sterile pipette at intervals of 4 to $12 \mathrm{~h}$ for 24 to $48 \mathrm{~h}$. Subsamples were fixed, stored and counted for bacteria as previously described.

The growth rate of bacteria $\left(\mu: \mathrm{h}^{-1}\right)$ was calculated for the exponential growth phase by linear regression analysis of the natural log of bacterial density (cells $\mathrm{ml}^{-1}$ ) versus incubation time (h). The significance of the regression was evaluated by the null hypothesis that $\mu=0$ ( $t$-test: Sokal \& Rohlf 1995).

\section{RESULTS}

\section{Environmental variables}

The annual range of temperature was 5.8 to $24.2^{\circ} \mathrm{C}$ (Fig. 3A). Temperature increased from March through August/September, and thermal stratification was observed between mid-May and August, with occasional mixing due to storms. After the end of September, water was mixed vertically and the temperature decreased (data presented in T. Tanaka 1998).

The concentration of total nitrogenous nutrients $\left(\mathrm{NO}_{2}+\mathrm{NO}_{3}+\mathrm{NH}_{4}\right)$ at $2 \mathrm{~m}$ at Stn 1 varied from 0.55 to $18.9 \mu \mathrm{M}$, being generally high from fall to winter (Fig. 3B). $\mathrm{NO}_{2}$ and $\mathrm{NO}_{3}$ varied in unison and were higher from October 1996 to February 1997. $\mathrm{NH}_{4}$ showed intensive short-term fluctuations, especially in August 1996, but was significantly higher from October 1996 to January 1997 than from February to May and September 1996 when monthly means were compared ( $t$-test, $\mathrm{p}<0.05$ ). The seasonal trend of $\mathrm{PO}_{4}$ was similar to $\mathrm{NO}_{2}$ and $\mathrm{NO}_{3}$, being high from fall to late winter (Fig. 3C). From spring to summer, the concentration of $\mathrm{PO}_{4}$ was low and occasionally less than the detection limit $(0.04 \mu \mathrm{M})$, usually for less than $5 \mathrm{~d}$, while nitrogenous nutrients were mostly $>1 \mu \mathrm{M}$. Chl a concentrations ranged from 0.15 to $6.4 \mu \mathrm{g} \mathrm{l}^{-1}$ and were high from early February to September 1996 and low from October 1996 to February 1997 (Fig. 3D). In Onagawa Bay, chl a peaks $>10 \mu \mathrm{g} \mathrm{l}^{-1}$ are usually observed in spring, summer and fall (e.g. Ishikawa 1995, Tanaka et al. 1997). Less pronounced peaks of chl a were observed in the present study for unknown reasons

\section{Bacterial and HNF abundance}

Bacterial abundance at $2 \mathrm{~m}$ ranged from $0.4 \times 10^{6}$ to $4 \times 10^{6}$ cells $\mathrm{ml}^{-1}$ with frequent short-term fluctuations (Fig. 4). The seasonal trend of bacterial abundance was weak, but statistically higher from May through October (except for July) than during the rest of the period in which monthly means were compared ( $t$-test, $\mathrm{p}<0.05$ ). HNF abundance ranged from $0.04 \times 10^{3}$ to $4.6 \times 10^{3}$ cells $\mathrm{ml}^{-1}$, showing a seasonal variation of 2 orders of magnitude (Fig. 4). HNF counts started to increase in April, and were higher from May through early October with temporal fluctuations up to 1 order of magnitude, and then decreased through January 1997 when monthly means were compared ( $t$-test, $\mathrm{p}<0.05$ ).

On shorter temporal scales, abundances of bacteria and HNF fluctuated in a regular cyclic manner with a variable lag phase between the two (Fig. 5). These coupled oscillations were observed previously at 0 , 2 and $5 \mathrm{~m}$ at the same site in July 1994 (Tanaka \& 

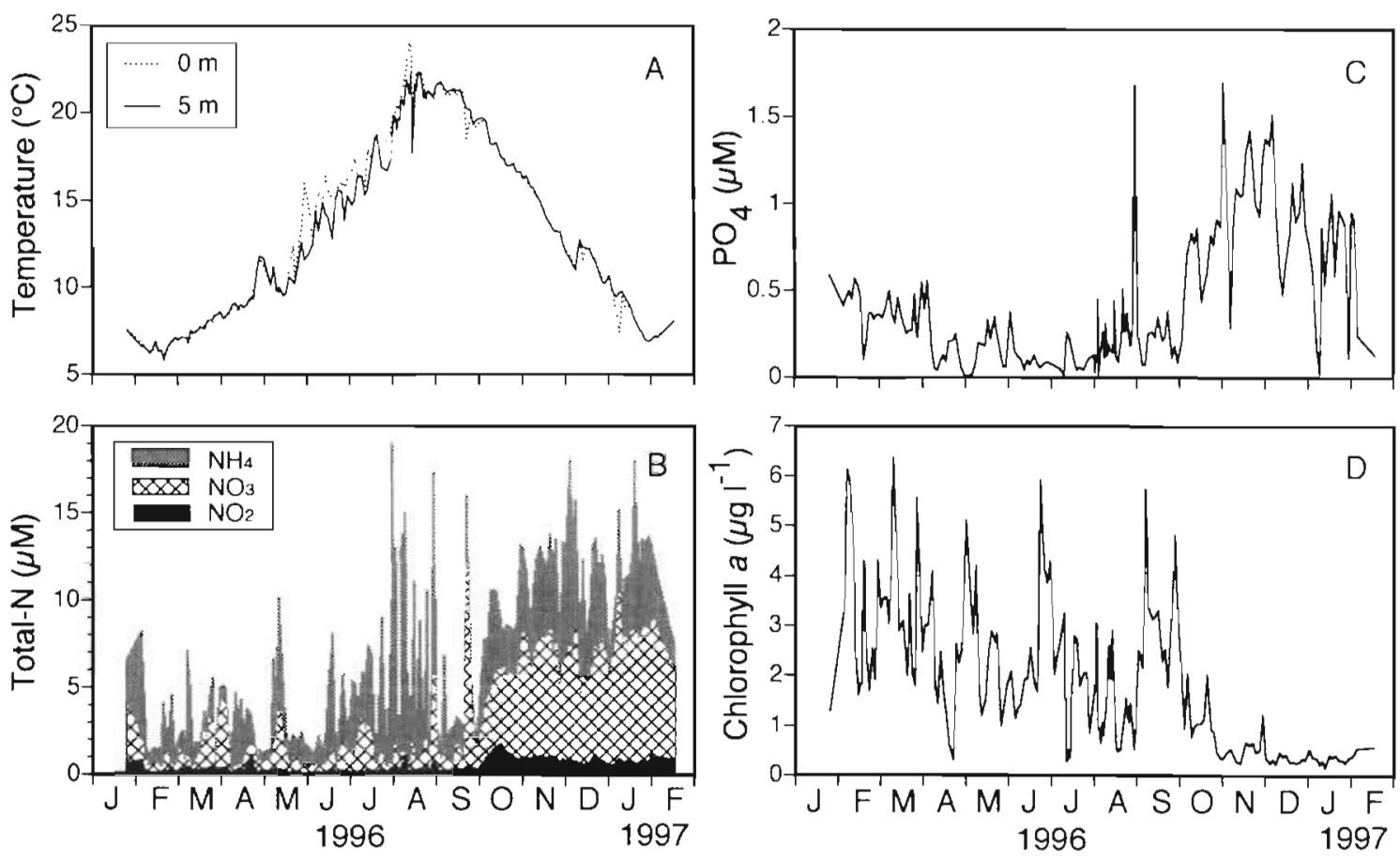

Fig. 3. Seasonal changes in (A) temperature, (B) nitrogenous nutrients $\left(\mathrm{NO}_{2}+\mathrm{NO}_{3}+\mathrm{NH}_{4}\right)$, (C) phosphate ( $\mathrm{PO}$ ), and (D) chlorophyll $a$ at Stn 1 during the period from January 1996 to February 1997

Taniguchi 1996, see their Figs. 3 to 5). In the present study, duplicate counts of HNF and bacteria were always conducted to minimize the counting error, however, it was occasionally difficult to determine the significant differences ( $t$-test, $\mathrm{p}<0.05$ ) between abundances enumerated with such a high temporal resolution. The cyclic fluctuations in bacterial abundance seemed to be more frequent (data not shown). This might be because bacterial and HNF abundances in nature reflect not only a direct predator-prey relationship but also seasonal trends and environmental factors. Thus, we deliberately set relaxed criteria to determine peak abundance, the period between peaks and the lag phase in predator-prey oscillations of the HNFbacteria system. The criteria we used were as follows: (1) abundance was considered to peak when its mean was higher than the mean abundance before and/or after it ( $t$-test, $p<0.1$ ), (2) the period is the duration between 2 proximate peaks of bacterial or HNF abundance and (3) the lag phase is the period between proximate peaks of bacterial and HNF abundance. For example, in June 1996, peaks of bacterial abundance were observed on Days 8, 15 and 24, and therefore, the periods were 7 and $9 \mathrm{~d}$ (Fig. 5E). A lag phase of 2 and $3 \mathrm{~d}$ was observed between the peaks of bacteria and HNF, i.e. Days 8 and 10, Days 24 and 27 respectively. These parameters of HNF-bacteria oscillations are summarized for each month in Table 1. Both the lag phase and the period were usually detected 2 or 3 times in each month, more frequently in August 1996, and only once in January 1997. Generally the lag phase ranged from 2 to $7 \mathrm{~d}$, while a '0' lag phase or a synchronized oscillation was observed in March, May, September and November in 1996. The 0 lag phase

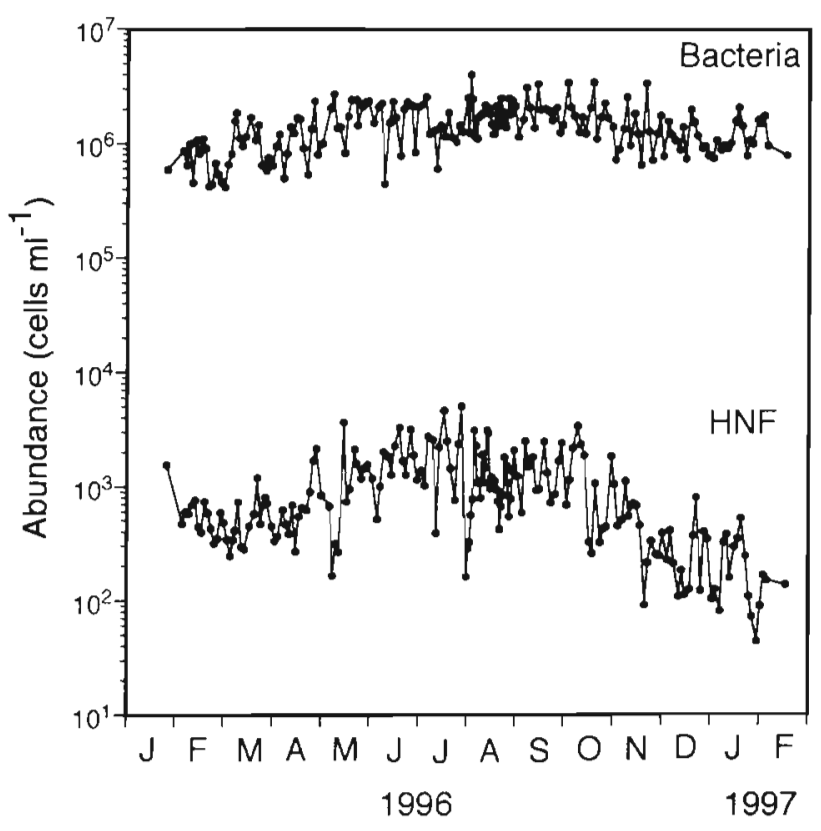

Fig. 4. Seasonal changes in abundance of bacteria and HNF at $2 \mathrm{~m}$ at Stn 1 from January 1996 to February 1997 

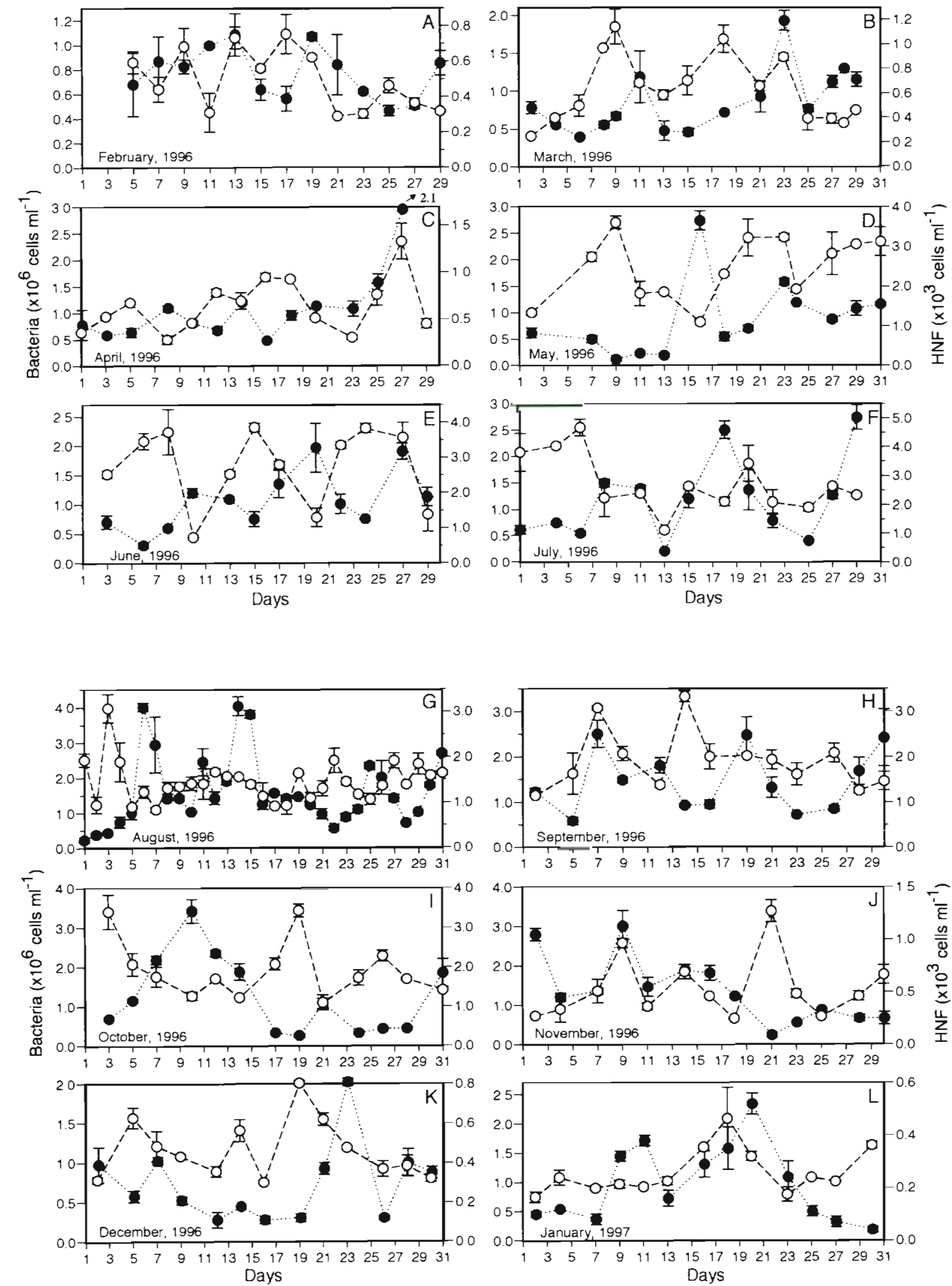

Fig. 5. Temporal changes in mean abundance of bacteria (0) and HNF $(\bullet) \pm 1 \mathrm{SE}(\mathrm{n}=2)$ at $2 \mathrm{~m}$ at Stn 1 during the period from February 1996 to January 1997 
Table 1. Lag phase between and periods of abundances of bacteria and HNF, determined from the data in Fig. 5 (February 1996 to January 1997). The criteria for determining lag and period are described in 'Bacterial and HNF abundance'

\begin{tabular}{|lccc|}
\hline Month & Lag phase & \multicolumn{2}{c|}{ Period (d) } \\
& (d) & Bacteria & HNF \\
\hline $\mathbf{1 9 9 6}$ & & 4,8 & 10 \\
February & 2,4 & 5,9 & 5 \\
March & $0^{\text {a }}$ & 11,11 & 6,15 \\
April & 2,3 & 8,14 & 7,8 \\
May & $0,0,7$ & 7,9 & 17 \\
June & 2,3 & 9,12 & 10,11 \\
July & $2,2,3$ & $2,2,7,8,9$ & $3,5,6,11$ \\
August & $2,2,3$ & 7,12 & 5,7 \\
September & 0,5 & $7,7,9$ & 10,11 \\
October & $2,5,7$ & $5,7,9$ & 5,11 \\
November & $0,0,4$ & 5,9 & 5,16 \\
December & 2,4 & 14 & 9 \\
1997 & \multicolumn{4}{|c}{} \\
January & 4 & 2 to 14 & 3 to 17 \\
Annual range & 0,2 to 7 & \multicolumn{3}{c}{} \\
a'0' lag: both bacterial and HNF peaks were detected on \\
the same day & \multicolumn{4}{l}{} \\
\hline
\end{tabular}

might be due to the sampling interval. On the other hand, uncoupled oscillations were occasionally observed, e.g. peaks in abundance on 16 April for bacteria and on 11 August for HNF (Fig. 5C,G). These results deviate from theory, indicating that other factors also influenced the HNF-bacteria relationship as outlined in the 'Discussion' section. Bacteria and HNF oscillated with 2 to $14 \mathrm{~d}$ and 3 to $17 \mathrm{~d}$ periods, respectively. There were no clear seasonal variations in the lag phase or the period.

These coupled oscillations were transcribed in phase space to analyze the behavior of the HNF-bacteria system. Although we assumed that the orbit of the HNF-bacteria system in phase space was continuous throughout the year, the data for September and December are presented as examples (Fig. 6). Each of the data sets was confined to a particular region which was graphically similar to that predicted by the classical predator-prey model (e.g. Lotka 1925, Volterra 1926 , 1939). Although the sequential movement showed both anticlockwise and clockwise directions in September and only anticlockwise in December, these results demonstrate that the HNF-bacterial relationship in nature is a predator-prey relationship and that the term predator-prey eddy (Tanaka et al. 1997) is a fitting description.

\section{Growth rates of bacteria}

Bacterial growth rates were measured almost weekly (43 occasions) throughout the year. Water tem-

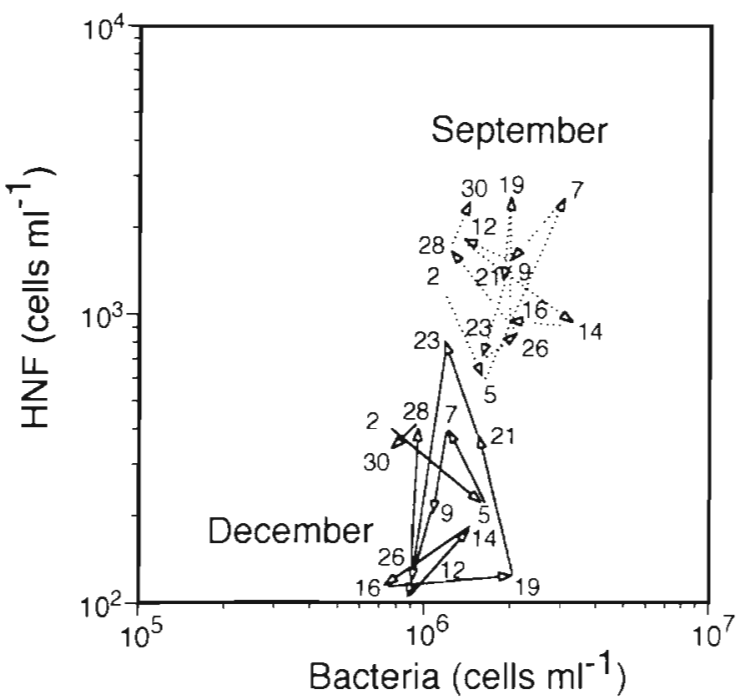

Fig. 6. Behavior of the HNF-bacteria system observed in September and December 1996 given in a 2-dimensional phase space (see Fig. 4). Arrows with dotted lines (September) and arrows with solid lines (December) are shown with the sampling day to mark the direction of the change

peratures ranged from 6.6 to $22.7^{\circ} \mathrm{C}$ in the incubation experiments. Bacterial growth rate ranged from 0.013 to $0.131 \mathrm{~h}^{-1}$ which corresponds to 0.5 to 4.6 divisions $\mathrm{d}^{-1}$ (Fig. 7). During the periods from June to November in 1996 and from May to June in 1997, growth rate was usually higher $\left(0.03\right.$ to $\left.0.1 \mathrm{~h}^{-1}\right)$, with short-term fluctuations, but generally $<0.03 \mathrm{~h}^{-1}$ from December 1996 to April 1997. Although the maximum value observed on 31 October 1996 was within the range of previous data (see White et al. 1991), it was assumed to be erroneous because: (1) bacterial growth was recorded only in the early half ( 6 to $12 \mathrm{~h}$ ) of the $33 \mathrm{~h}$ incubation and (2) the in situ chl a concentration $\left(0.33 \mu \mathrm{g} \mathrm{l}^{-1}\right)$ was as

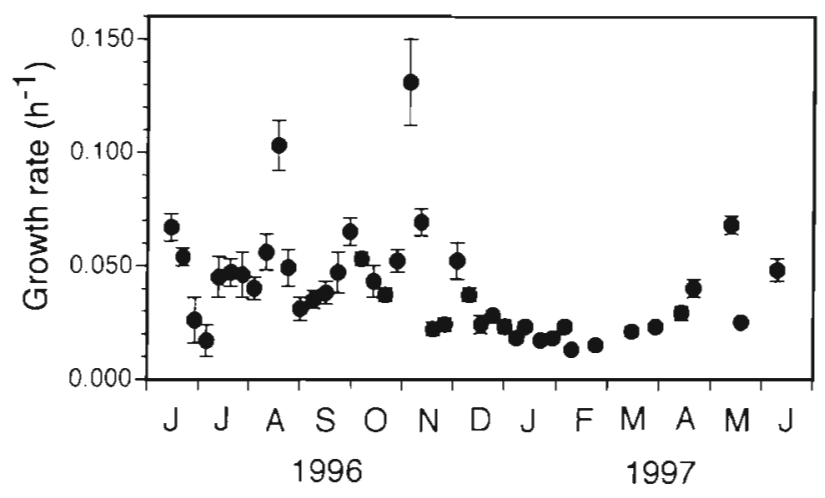

Fig. 7. Seasonal changes of mean specific growth rate $\left(\mathrm{h}^{-1}\right)$ of bacteria $\pm 1 \mathrm{SE}$ ( $\mathrm{n}=4$ to 12 ) from June 1996 to June 1997. If error bars are not visible, they are less than the size of the symbol 
low as in the following winter when bacterial growth was also low. Therefore, this value was excluded from the following discussion.

\section{DISCUSSION}

\section{Seasonal and short-term variations}

It has been reported for temperate waters that the bacterial growth rate is likely influenced by temperature, and sometimes by substrate supply, especially in warmer seasons (Scavia \& Laird 1987, Hoch \& Kirchman 1993, Shiah \& Ducklow 1994). In Onagawa Bay, as expected from the marked seasonality of environmental variables like temperature and chl $a$, the bacterial growth rate also showed distinct seasonal variation, being higher in warmer seasons and vice versa (Fig. 7). Our results demonstrate that growth of the bacterial populations in the bay is always positive $(p<0.05)$. This implies that bacterial abundance in nature was usually below the carrying capacity of the bay. Nevertheless, as observed in our previous study (Tanaka et al. 1997), the seasonal variation of the bacterial abundance in situ was only 1 order of magnitude (Fig. 4). This contradictory phenomenon of a high growth capability but only small increases in abundance could be explained by the so-called top-down control by predators which can quickly remove increasing bacteria. On the other hand, the lower values of bacterial abundance in the bay corresponded to reported values of a feeding threshold for HNF on bacteria (e.g. Fenchel 1982b, Andersen \& Fenchel 1985, Wikner \& Hagström 1991). Therefore, the observed narrow range of seasonal variation of bacterial abundance can be explained by both the intensive feeding by HNF on increasing bacteria and the inability of HNF to feed on bacteria at lower densities.

Our results also reveal that both HNF and bacterial abundances in nature continually fluctuate on shorter temporal scales throughout the year, although our criterion for the determination of peaks does not premit extensive statistical treatment (Fig. 5). However, 60\% of bacterial peaks and $74 \%$ of HNF peaks were significantly higher than both the mean abundances before and after the peaks $(p<0.05)$. It is quite interesting that lags of 2 to $7 \mathrm{~d}$ between bacterial and HNF fluctuations with 2 to $17 \mathrm{~d}$ periods are in general agreement with previously reported values: ca 4 d lags between both fluctuations with ca $16 \mathrm{~d}$ periods in August/September (Fenchel 1982d) and 3 to $8 \mathrm{~d}$ lags with 7 to $23 \mathrm{~d}$ periods from March to November (Andersen \& Sorensen 1986) in Limfjorden, Denmark, and 1 to 3 d lags with 5 to $10 \mathrm{~d}$ periods in July/August in Seto Inland Sea, Japan (Nakamura et al. 1994), as well as our previous data from Onagawa Bay, i.e. 2 to $6 \mathrm{~d}$ lags with 4 to $10 \mathrm{~d}$ periods in July 1994 (Tanaka \& Taniguchi 1996).

Theoretically, abundances of populations with 1 predator type and 1 prey type should oscillate with similar periods and a lag phase which is about $1 / 4$ of its periad (Lotka 1925, Volterra 1926, 1939). However, because both abundances showed a variety of fluctuations, predator-prey oscillations between HNF and bacteria were occasionally not clear, i.e. synchronized and uncoupled oscillations (Fig. 5, Table 1). When the monitoring is conducted in nature, the following factors may cause this variability in lag and period: (1) difficulties in monitoring the succession of such predatorprey populations due to sampling interval, physical disturbances (e.g. current, storms and advection) and diverse microniches (cf. Davis et al. 1985, Azam 1998), (2) fluctuations of bacterial substrates, i.e. dissolved organic matter from phytoplankton and zooplankton (e.g. Webb \& Johannes 1967, Larsson \& Hagström 1982, Andersson et al. 1985), (3) infection of bacteria or HNF by viruses (e.g. Proctor \& Fuhrman 1990, Nagasaki et al. 1993), (4) predation on bacteria by other organisms than HNF (Bird \& Kalff 1986, Sherr \& Sherr 1987), (5) predation on HNF (e.g. Sanders \& Wickham 1993) and (6) availability of HNF food sources other than bacteria (e.g. Campbell \& Carpenter 1986, Parslow et al. 1986, Sherr 1988). In addition, we monitored abundances of HNF and bacteria at the community level and observed that different sets of species of HNF bloomed and crashed over a season and some even within a week.

Since the innermost part of Onagawa Bay is a semienclosed embayment without significant inflow of freshwater and the maximum change in depth to the bottom at Stn 1 is ca $1.5 \mathrm{~m}$, a quick and/or substantial replacement of the water mass seems to be unlikely at this study site. A clear relationship between HNF and bacterial abundances and the tidal cycle was not evident from diel observations at $2 \mathrm{~h}$ intervals (Tanaka 1995). To evaluate the influence of advection, we compared the mean of the bacterial growth rate with the rate of increase in bacterial abundance in situ for each month from June 1996 to January 1997. The rate of increase was calculated from each successive 2 data points by assuming an exponential increase in bacterial abundance. However, because the rate of increase in abundance never exceeded the mean of the bacterial growth rate (data not shown), we do not believe that advection profoundly affected our results.

The bacterial growth rate showed short-term fluctuations (Fig. 7) and may have been influenced by fluctuations in bacterial substrates and/or viral activities. However, the growth rate was always positive ( $p<$ 0.05 ), which would imply that the bacterial growth rate or abundance in this bay was not highly depressed by 
either substrates or viral activity. Total ciliates (heterotrophic and mixotrophic naked and tintinnid forms) and total dinoflagellates (heterotrophic naked and thecate forms) varied from 2 to 83 cells $\mathrm{ml}^{-1}$ and from 4 to 68 cells $\mathrm{ml}^{-1}$, respectively, at the same site and were abundant from spring to summer in 1997 (M. Tanaka 1998); either group may have consumed bacteria and/or HNF. Copepods dominated by Acartia clausi were abundant in summer (total abundance $9 \times 10^{3}$ to $3 \times 10^{4}$ ind. $\mathrm{m}^{-3}$ ) in Onagawa Bay (Uye 1980) and may have preyed on HNF. Cyanophyte abundance ranged from < 10 to $9.2 \times 10^{4}$ cells $\mathrm{ml}^{-1}$ from January 1996 to February 1997 and was higher from June to September (mean $1.0 \times 10^{4}$, range $9 \times 10^{1}$ to $9.2 \times 10^{4} \mathrm{cells}^{-1}$, unpubl. data). Because the feeding threshold for HNF on cyanophytes was predicted to be $6 \times 10^{4}$ cells $\mathrm{ml}^{-1}$ by Landry et al. (1984) and cyanophyte abundance was only sporadically higher than this threshold in Onagawa Bay, the utilization of cyanophytes might not be common for HNF. Although prochlorophytes may be available to HNF (e.g. Landry et al. 1995), we did not enumerate them due to their dim and fast-fading autofluorescence under the epifluorescence microscope (Monger \& Landry 1993). However, recent observations demonstrate that prochlorophytes are truly oceanic organisms, largely distributed in the deeper part of the euphotic layer in the oligotrophic oceans (Lindell \& Post 1995, Buck et al. 1996). Therefore, if they are distributed in Onagawa Bay, their contribution to the HNF diet does not appear to be significant.

On the other hand, Parslow et al. (1986) suggested that the response of HNF to fluctuating densities of autotrophic picoplankton might be intrinsically complicated even in continuous cuiture experiments with populations of only 1 type of predator and 1 type of prey. Thus, it is difficult to identify and/or isolate each factor which may cause a deviation from the theoretical model. One of the important findings in this study is that the predator-prey oscillations are usually stable throughout the year in spite of so many possible variables. Furthermore, the previous reports mentioned above showed similar trends to those observed in the present study although temporal and spatial conditions were different. Therefore, it seems that similar relationships between HNF and bacteria in nature might exist, both in terms of lags and periodicities over longer temporal and wider geographical ranges, at least in the northern temperate zone (T. Tanaka 1998).

\section{Predator-prey eddy in the HNF-bacteria system}

On a monthly basis, the position of an HNF-bacteria eddy was confined to a particular region in phase space (Fig. 6), in spite of sporadic and sometimes dras- tic changes in environmental variables (cf. Fig. 3). The eddy's position and magnitude varied between seasons (Fig. 6). These trends were also shown in the other months (T. Tanaka 1998). The annual behavior of the eddies could be illustrated by calculating their monthly means (Fig. 8). As was shown in a previous study (Tanaka et al. 1997, see their Fig. 5), because of relatively small seasonal variation of bacterial abundance, the eddy was confined to a vertically elongated elliptical region in phase space. Interestingly, this relationship seems to be similar to one of the steady-state solutions in the model used by Thingstad et al. (1997), in which bacterial abundance remains constant while HNF abundance increases with the system's nutrient richness. These results support our contention that the predator-prey eddy of the HNF-bacteria system always exists and continuously migrates over a certain range of phase space on an annual basis.

All the data on HNF and bacterial abundances from this study and from our previous study (Tanaka et al. 1997) are plotted in phase space to consider the region where the HNF-bacteria system in Onagawa Bay might be confined (Fig. 9). Because the seasonal variation of chl a concentration was smaller in the present study (mean 1.8, range 0.15 to $6.4 \mu \mathrm{g} \mathrm{l}^{-1}$ ) than in the previous one (mean 4.3 , range 0.35 to $18.9 \mu \mathrm{g} \mathrm{l}^{-1}$ ), a difference in the position and magnitude of the region was to be expected. In fact, it seems that the previous data (Fig. 9a) were more scattered $\left(0.2 \times 10^{6}\right.$ to $4 \times$ $10^{6}$ cells $\mathrm{ml}^{-1}$ for bacteria, $0.03 \times 10^{3}$ to $6.7 \times 10^{3}$ cells $\mathrm{ml}^{-1}$ for HNF) than the present data (Fig. 9b, $0.4 \times 10^{6}$

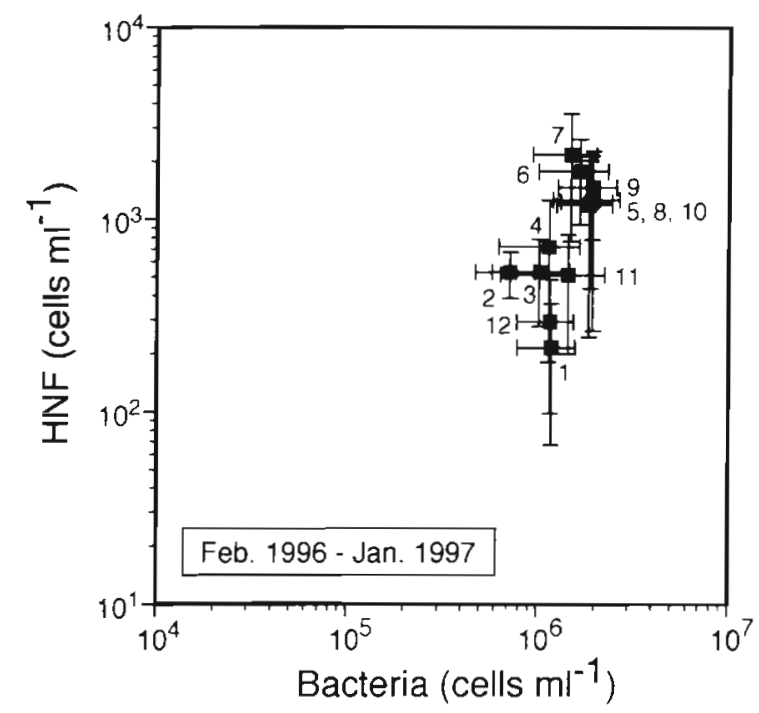

Fig. 8. Seasonal relationship between abundance of HNF and bacteria from monthly means with standard deviations for all individual points at $2 \mathrm{~m}$ at $\mathrm{Stn} 1$ during the period from February 1996 to January 1997. Each number shows the corresponding month 


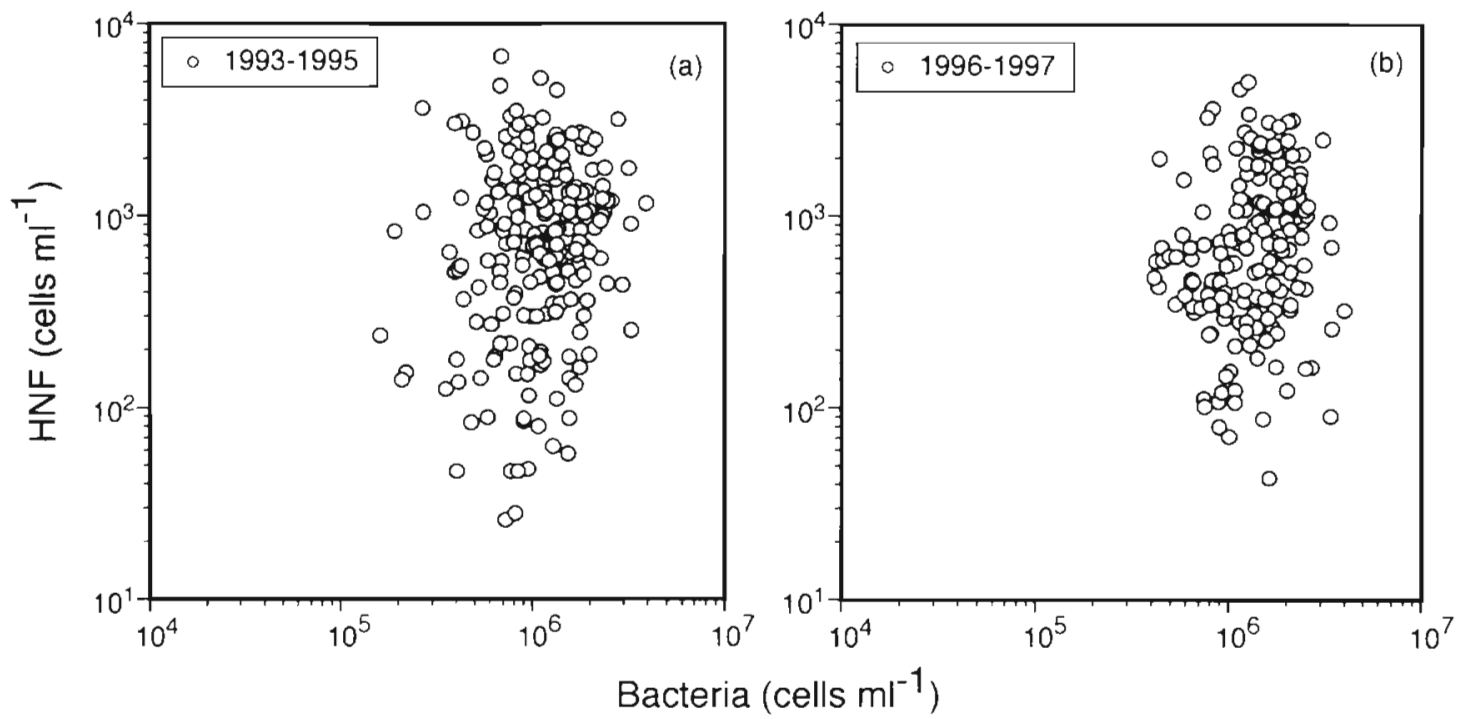

Fig. 9. HNF abundance versus bacterial abundance observed at Stn 1 during the periods (a) from December 1993 to March 1995 at 0,2 and $5 \mathrm{~m}(\mathrm{n}=227$, data from Tanaka et al. 1997) and (b) from January 1996 to February 1997 at $2 \mathrm{~m}(\mathrm{n}=180$ )

to $4 \times 10^{6}$ cells $\mathrm{ml}^{-1}$ for bacteria, $0.04 \times 10^{3}$ to $4.6 \times$ $10^{3}$ cells $\mathrm{ml}^{-1}$ for $(\mathrm{NF})$, however, this might have been caused by a difference in the counting methods, i.e. single versus duplicate counts were done respectively in the previous and the present series (cf. 'Materials and methods', Tanaka et al. 1997). Therefore, the data obtained in both series were confined to a very similar region, i.e. a vertically elongated elliptical region. This result suggests the existence of a particular region in the HNF-bacteria system in Onagawa Bay, which confines the eddy to a particular region in phase space.

\section{Concluding remarks}

Recent studies have revealed that the microbial loop is a more complicated and dynamic process than previously thought (e.g. Bergh et al. 1989, Koike et at. 1990, Nagata \& Kirchman 1992, Fuhrman \& Noble 1995). Our data are limited to just 2 components of the microbial loop, i.e. HNF and bacteria. However, our data demonstrate that a tightly and stably coupled relationship between the 2 components exists in nature; this relationship can be described as a predator-prey eddy in phase space, staying in a particular region on shorter temporal scales, while migrating seasonally. In addition, several cross-ecosystem analyses have shown that HNF and/or bacterial abundances tend to increase with increases in chl a or primary production (e.g. Cole et al. 1988, Sanders et al. 1992). These facts seem to suggest that, on an annual basis, the numerical relationship in each system is confined to a particular region in phase space and that this region is likely determined by the annual range of local environmental conditions. If so, the scheme proposed by Tanaka et al. (1997) is not only valid in Onagawa Bay but is also applicable to aquatic systems over wide geographical ranges.

Acknowledgements. We thank N. Yamada, Sendai Institute for Hygiene, for his advice about preparation and enumeration techniques for bacteria and HNF and K. Haraguchi and $K$. Matsuzaki of Tohoku University, for their assistance in nutrient analysis. We also thank the staff of Onagawa Marine Laboratory, Tohoku University, for their advice on sampling. This research was partially funded by Grant No. 06839003 from the Japanese Ministry of Education, Science and Culture and by the Sasakawa Scientific Research Grant from The Japan Science Society. We are indebted to Prof. P. J. Harrison, University of British Columbia (temporarily visiting Tohoku University), for his constructive comments and linguistic corrections.

\section{LITERATURE CITED}

Andersen P, Fenchel T (1985) Bacterivory by microheterotrophic flagellates in seawater samples. Limnol Oceanogr 30:198-202

Andersen P. Sorensen HM (1986) Population dynamics and trophic coupling in pelagic microorganisms in eutrophic coastal waters. Mar Ecol Prog Ser 33:99-109

Andersson A, Lee C, Azam F, Hagström $\AA$ (1985) Release of aminoacids and inorganic nutrients by heterotrophic marine microflagellates. Mar Ecol Prog Ser 23: $99-106$

Azam F (1998) Microbial control of oceanic carbon flux: the plot thickens. Science 280:694-696

Azam F, Fenchel T, Field JG, Gray JS, Meyer-Reil LA, Thingstad $F$ (1983) The ecological role of water-column microbes in the sea. Mar Ecol Prog Ser 10:257-263 
Bergh $\varnothing$, Børsheim KY, Bratbak G, Heldal M (1989) High abundance of viruses found in aquatic environments. Nature 340:467-468

Berninger UG, Finlay BJ, Kuuppo-Leinikki P (1.991) Protozoan control of bacterial abundances in freshwater. Limnol Oceanogr 36:139-147

Bird DF, Kalff J (1986) Bacterial grazing by planktonic lake algae. Science 231:493-495

Buck KR, Chavez FP, Campbell L (1996) Basin-wide distributions of living carbon components and the inverted trophic pyramid of the central gyre of the North Atlantic Ocean, summer 1993. Aquat Microb Ecol 10:283-298

Campbell L, Carpenter EJ (1986) Estimating the grazing pressure of heterotrophic nanoplankton on Synechococcus spp. using the sea water dilution and selective inhibitor techniques. Mar Ecol Prog Ser 33:121-129

Cole JJ, Findlay S, Pace ML (1988) Bacterial production in fresh and saltwater ecosystems: a cross-system overview. Mar Ecol Prog Ser 43:1-10

Davis PG, Caron DA, Johnson PW, Sieburth JMCN (1985) Phototrophic and apochlorotic components of picoplankton and nanoplankton in the North Atlantic: geographic, vertical, seasonal and diel distributions. Mar Ecol Prog Ser $21: 15-26$

Fenchel T (1982a) Ecology of heterotrophic microflagellates. I. Some important forms and their functional morphology. Mar Ecol Prog Ser 8:211-223

Fenchel T (1982b) Ecology of heterotrophic microflagellates. II. Bioenergetics and growth. Mar Ecol Prog Ser 8: 225-231

Fenchel T (1982c) Ecology of heterotrophic microflagellates. IIl. Adaptations to heterogeneous environments. Mar Ecol Prog Ser 9:25-33

Fenchel T (1982d) Ecology of heterotrophic microflagellates. IV. Quantitative occurrence and importance as bacterial consumers. Mar Ecol Prog Ser 9:35-42

Fenchel T (1986) The ecology of heterotrophic microflagellates. Adv Microb Ecol 9:57-97

Ferguson RL, Buckley EN, Palumbo AV (1984) Response of marine bacterioplankton to differential filtration and confinement. Appl Environ Microbiol 47:49-55

Fitzwater SE, Knauer GA, Martin JH (1982) Metal contamination and its effect on primary production measurements. Limnol Oceanogr 27:544-551

Fuhrman JA, Noble RT (1995) Viruses and protists cause similar bacterial mortality in coastal seawater. Limnol Oceanogr 40:1236-1242

Gasol JM, Vaqué D (1993) Lack of coupling between heterotrophic nanoflagellates and bacteria: a general phenomenon across aquatic systems? Limnol Oceanogr 38:657-665

Goldman JC, Caron DA (1985) Experimental studies on an omnivorous microflagellate: implications for grazing and nutrient regeneration in the marine microbial food chain. Deep-Sea Res 32:899-915

Güde $\mathrm{H}$ (1986) Loss processes influencing growth of planktonic bacterial populations in Lake Constance. J Plankton Res 8:795-810

Haas LW (1982) Improved epifluorescence microscopic technique for observing planktonic micro-organisms. Ann lnst Oceanogr, Paris 58(S):261-266

Hoch MP, Kirchman DL (1993) Seasonal and inter-annual variability in bacterial production and biomass in a temperate estuary. Mar Ecol Prog Ser 98:283-295

Ishikawa A (1995) Population dyanamics of Scrippsiella spp. and other cyst-forming armored dinoflagellates with special reference to the role of cysts. PhD thesis, Tohoku Univ, Sendai
Iwamoto N, Imai I, Uye S (1994) Seasonal fluctuation in abundance of bacteria, heterotrophic nanoflagellates, autotrophic nanoflagellates and nanodiatoms in Hiroshima Bay, the Inland Sea of Japan. Bull Plankton Soc Jpn 41:31-42

Koike I, Hara S, Terauchi K, Kogure K (1990) Role of submicrometre particles in the ocean. Nature 345:242-244

Landry MR, Haas LW, Fagerness VL (1984) Dynamics of microbial plankton communities: experiments in Kaneohe Bay, Hawaii. Mar Ecol Prog Ser 16:127-133

Landry MR, Kirshtein J, Constantinou J (1995) A refined dilution technique for measuring the community grazing impact of microzooplankton, with experimental tests in the central equatorial Pacific. Mar Ecol Prog Ser 120:53-63

Larsson U, Hagström $\AA$ (1982) Fractionated phytoplankton primary production, exudate release and bacterial production in a Baltic eutrophication gradient. Mar Biol 67:57-70

Lindell D, Post AF (1995) Ultraphytoplankton succession is triggered by deep winter mixing in the Gulf of Aqaba (Eilat), Red Sea. Limnol Oceanogr 40:1130-1141

Lotka AJ (1925) Elements of physical biology. Williams and Wilkins, Baltimore (1956; reprint, Elements of mathematical biology, Dover Publications, New York)

Monger BC, Landry ML (1993) Flow cytometric analysis of marine bacteria with Hoechst 33342. Appl Environ Microbiol 59:905-911

Mostajir B, Dolan JR, Rassoulzadegan F (1995) Seasonal variations of pico- and nano-detrital particles (DAPI yellow particles, DYP) in the Ligurian Sea (NW Mediterranean). Aquat Microb Ecol 9:267-277

Nagasaki K, Ando M. Imai I, Itakura S, Ishida Y (1993) Viruslike particles in an apochlorotic flagellate in Hiroshima Bay, Japan. Mar Ecol Prog Ser 96:307-310

Nagata T, Kirchman DL (1992) Release of macromolecular organic complexes by heterotrophic marine flagellates. Mar Ecol Prog Ser 83:233-240

Nakamura Y, Fukami K, Sasaki S, Hiromi J (1994) Population dynamics of bacteria and heterotrophic nanoflagellates following the summer diatom bloom in the Seto Inland Sea. Bull Plankton Soc Jpn 41:1-8

Parslow JS, Doucette GJ, Taylor FJR, Harrison PJ (1986) Feeding by the zooflagellate Pseudobodo sp. on the picoplanktonic prasinomonad Micromonas pusilla. Mar Ecol Prog Ser 29:237-246

Parsons TR, Maita Y, Lalli CM (1984) A manual of chemical and biological methods for seawater analysis. Pergamon Press, Oxford

Porter KG, Feig YS (1980) The use of DAPI for identifying and counting aquatic microflora. Limnol Oceanogr 25:943-948

Proctor LM, Fuhrman JA (1990) Viral mortality of marine bacteria and cyanobacteria. Nature 343:60-62

Sanders RW. Wickham SA (1993) Planktonic Protozoa and Metazoa: predation, food quality and population control. Mar Microb Food Webs 7:197-223

Sanders RW, Caron DA, Berninger UG (1992) Relationships between bacteria and heterotrophic nanoplankton in marine and fresh waters: an inter-ecosystem comparison. Mar Ecol Prog Ser 86:1-14

Sasaki K, Aoyagi K, Arai N (1995) Bottom sediments of Onagawa Bay, Miyagi. Bull Jpn Soc Fish Oceanogr 59: 241-249 (in Japanese with English abstract)

Scavia D, Laird GA (1987) Bacterioplankton in Lake Michigan: dynamics, controls, and significance to carbon flux. Limnol Oceanogr 32:1017-1033

Sherr BF, Sherr EB (1991) Proportional distribution of total numbers, biovolume, and bacterivory among size classes of 2-20 $\mu \mathrm{m}$ nonpigmented marine flagellates. Mar Microb Food Webs 5:227-237 
Sherr BF, Sherr EB, Andrew TL, Fallon RD, Newell SY (1986) Trophic interactions between heterotrophic Protozoa and bacterioplankton in estuarine water analyzed with selective metabolic inhibitors. Mar Ecol Prog Ser 32:169-179

Sherr EB (1988) Direct use of high molecular weight polysaccharide by heterotrophic flagellates. Nature 335:348-351

Sherr EB, Sherr BF (1987) High rates of consumption of bacteria by pelagic ciliates. Nature 325:710-711

Shiah FK, Ducklow HW (1994) Temperate regulation of heterotrophic bacterioplankton abundance, production, and specific growth rate in Chesapeake Bay. Limnol Oceanogr 39: $1243-1258$

Sokal RR, Rohlf FJ (1995) Biometry, 3rd edn. WH Freeman and Company, New York

Tanaka M (1998) Seasonal change in standing crop of heterotrophic dinoflagellates and ciliates in Onagawa Bay, on the Pacific coast of northeastern Honshu, Japan. M Agr Sci thesis, Tohoku Univ, Sendai (in Japanese with English abstract)

Tanaka $\mathrm{T}$ (1995) Seasonal and short-term changes in abundance of pico- and nanoplankton communities in Onagawa Bay, northeast Japan. M Agr Sci thesis, Tohoku Univ, Sendai (in Japanese with English abstract)

Tanaka $T$ (1998) Dynamics of the heterotrophic nanoflagellate-bacteria associations in a coastal marine environment. PhD thesis, Tohoku Univ, Sendai

Tanaka T, Taniguchi A (1996) Short-term variation in abundance of bacteria and heterotrophic nanoflagellates in summer observed in Onagawa Bay, Japan. Bull Plankton Soc Jpn 43:21-29

Tanaka T, Fujita N, Taniguchi A (1997) Predator-prey eddy in heterotrophic nanoflagellate-bacteria relationships in a coastal marine environment: a new scheme for predatorprey associations. Aquat Microb Ecol 13:249-256

Thingstad TF, Hagström $\AA$, Rassoulzadegan F (1997) Accumulation of degradable DOC in surface waters: is it caused

Editorial responsibility: Tom Fenchel (Contributing Editor), Helsingør, Denmark by a malfunctioning microbial loop? Limnol Oceanogr 42 : $398-404$

Uye S (1980) Population dynamics and production of Acartia clausi (Copepod: Calanoida) in inlet waters. PhD thesis, Tohoku Univ, Sendai

van Es FB, Meyer-Reil LA (1982) Biomass and metabolic activity of heterotrophic marine bacteria. Adv Microb Ecol 6:111-170

Volterra $V(1926)$ Fluctuations in the abundance of a species considered mathematically. Nature 188:558-560

Volterra V (1939) Variation and fluctuations of the number of individuals in animal species living together Appendix. In: Chapman RN (ed) Animal ecology. McGraw-Hill, New York, p 409-448. First published in $\mathrm{J}$ Cons Int Explor Mer (1928). Vol 1 (in French)

Webb KL, Johannes RE (1967) Studies of the release of dissolved free amino acids by marine zooplankton. Limnol Oceanogr 12:376-382

White PA, Kalff J, Rasmussen JB, Gasol JM (1991) The effect of temperature and algal biomass on bacterial production and specific growth rate in freshwater and marine habitats. Microb Ecol 21:99-118

Wikner J, Hagström $\AA$ (1991) Annual study of bacterioplankton community dynamics. Limnol Oceanogr 36: $1313-1324$

Wright RT, Coffin RB (1984a) Factors affecting bacterioplankton density and productivity in salt marsh estuaries. In: Klug MJ, Reddy CA (eds) Current perspectives in microbial ecology. American Society for Microbiology, Washington, DC, p 485-494

Wright RT, Coffin RB (1984b) Measuring microzooplankton grazing on planktonic marine bacteria by its impact on bacterial production. Microb Ecol 10:137-149

Yentsch CS, Menzel DW (1963) A method for determination of phytoplankton chlorophyll and phaeophytin by fluorescence. Deep-Sea Res 10:221-231

Submitted: June 15, 1998; Accepted: November 21, 1998 Proofs received from author(s): March 24, 1999 